\title{
Trichoderma spp. decrease Fusarium root rot in common bean
}

\author{
Hudson Teixeira ${ }^{1}$, Trazilbo José de Paula Júnior ${ }^{2}$, Rogério Faria Vieira², Marcelo Barreto da Silva ${ }^{3}$, Camila Geovana \\ Ferro $^{2}$, Miller da Silva Lehner ${ }^{2}$
}

${ }^{1}$ EPAMIG, CP 176, 37200-000, Lavras, MG, Brazil; ${ }^{2}$ EPAMIG, Vila Gianetti 47, 36570-000, Viçosa, MG, Brazil; ${ }^{3} \mathrm{CEUNES/UFES,} \mathrm{29931-220,}$ São Mateus, ES, Brazil. E-mail: trazilbo@epamig.br, rfvieira@epamig.br, barretofito@uol.com.br, camila.ferro@ufv.br, millerlehner@gmail.com. Autor para correspondência: Hudson Teixeira (hudsont@epamig.br)

Data de chegada: 16/02/2012. Aceito para publicação em: 21/08/2012.

\section{ABSTRACT}

Teixeira, H.; Paula Júnior, T.J.; Vieira, R.F.; Silva, M.B.; Ferro, C.G.; Lehner, M.S. Trichoderma spp. decrease Fusarium root rot in common bean. Summa Phytopathologica, v.38, n.4, p.334-336, 2012.

The effectiveness of six Trichoderma-based commercial products (TCP) in controlling Fusarium root rot (FRR) in common bean was assessed under field conditions. Three TCP, used for seed treatment or applied in the furrow, increased seedling emergence as much as the fungicide fludioxonil. FRR incidence was not affected, but all TCP and fludioxonil reduced the disease severity, compared to control. Application of Trichoderma-based products was as effective as that of fludioxonil in FRR management.

Additional keywords: Phaseolus vulgaris, biological control, soilborne pathogen.

\section{RESUMO}

Teixeira, H.; Paula Júnior, T.J.; Vieira, R.F.; Silva, M.B.; Ferro, C.G.; Lehner, M.S. Trichoderma spp. reduzem a podridão-radicular de Fusário em feijoeiro comum. Summa Phytopathologica, v.38, n.4, p.xxx-xxx, 2012.

A eficácia de seis produtos comerciais à base de Trichoderma (PCT) no controle da podridão-radicular-seca do feijoeiro (PRS) foi avaliada em condições de campo. Três PCT, usados no tratamento de sementes ou aplicados no sulco de plantio, aumentaram a emergência das plântulas tanto quanto o fungicida fludioxonil. A incidência de PRS não foi afetada, mas todos os PCT e o fludioxonil reduziram a severidade em relação à testemunha. A aplicação de produtos à base de Trichoderma spp. foi tão eficaz quanto o fludioxonil no manejo da PRS.

Palavras-chave adicionais: Phaseolus vulgaris, controle biológico, patógeno de solo.

Fusarium root rot (FRR) is caused by Fusarium solani f. sp. phaseoli W.C. Snyder \& H.N. Hansen $(F s p)$ and is a widely distributed disease of common bean (Phaseolus vulgaris L.) in Brazil. Besides the cultural practices, biological control may reduce Fsp activities (7). In Brazil, several commercial products containing propagules of Trichoderma spp. have been commercialized to control plant diseases, but their quality is unknown $(3,9)$ and their efficacy against FRR in common bean has been scarcely reported $(2,7)$.

A field experiment was carried out at EPAMIG (Oratórios, MG, Brazil - 20²4'11" S, 4249'08" W, elevation $478 \mathrm{~m}$ ) to evaluate the effectiveness of six Trichoderma products in controlling FRR. Historically, Fsp inoculum in this area is uniformly distributed. Trichoderma-based commercial products (TCP) were used strictly as recommended by the manufacturer (Table 1). Seed treatment with the fungicide fludioxonil and an untreated control were used for comparisons. The cultivar Ouro Vermelho (type II/III, red seeds) was sown on July 16, 2008. Plots consisted of four rows that were $0.5 \mathrm{~m}$ apart and $2 \mathrm{~m}$ long. Fifteen seeds per meter were distributed in the furrow with subsequent thinning at $\mathrm{V} 2$ growth stage to 10 plants per meter. A completely randomized block design with six replicates was used. At planting, $600 \mathrm{~kg} \mathrm{ha}^{-1}$ of $4 \mathrm{~N}: 14 \mathrm{P}_{2} \mathrm{O}_{5}: 8 \mathrm{~K}_{2} \mathrm{O}$ was applied. Urea $\left(100 \mathrm{~kg} \mathrm{ha}^{-1}\right)$ was applied as a side dressing at V3 stage. At this time, plants were also sprayed with a sodium molybdate solution $\left(200 \mathrm{~g} \mathrm{ha}^{-1}\right)$. Irrigation using overhead sprinklers was provided $(\sim 40 \mathrm{~mm}$ of water per week). Angular leaf spot was prevented with azoxystrobin (50 g $\mathrm{ha}^{-1}$ ) in R6. The disease incidence was calculated as the percentage of plants with FRR symptoms. Plants were rated for severity according to Abawi \& Pastor-Corrales (1) and the disease severity index (DSI) was calculated on a percentage basis: DSI $(\%)=\Sigma$ (scores of all plants) / [9 x (total number of plants) $] \times 100$. Fsp population density was determined as the number of colony-forming units (cfu) $\mathrm{g}^{-1}$ of soil. Soil samples were collected in the rows from the upper $10 \mathrm{~cm}$ of soil soon after bean plants were removed for disease evaluation. Ten samples from each plot had been mixed before $1.0 \mathrm{~g}$ of soil was suspended in water to reach a concentration of $0.1 \mathrm{mg} \mathrm{L}^{-1}$. Thereon, each sample was placed on Petri dishes with PCNB-peptone-agar medium. The dishes were incubated in darkness for 48 hours at $22^{\circ} \mathrm{C}$, followed by cfu assessment. Yield was estimated based on the mass of seeds with $12 \%$ moisture $\left(\mathrm{w} \mathrm{w}^{-1}\right)$ harvested in two central lines.

Four out of six TCP and the fungicide fludioxonil provided a more rapid (data not shown) and greater emergence of seedlings, compared to the untreated control (Table 1). Trichodermil SC ${ }^{\circledR}$ and Trichodermax 
Table 1. Effects of Trichoderma-based commercial products on seedlings emergence, population of Fusarium solani f. sp. phaseoli (Fsp), intensity of Fusarium root rot and yield in common bean.

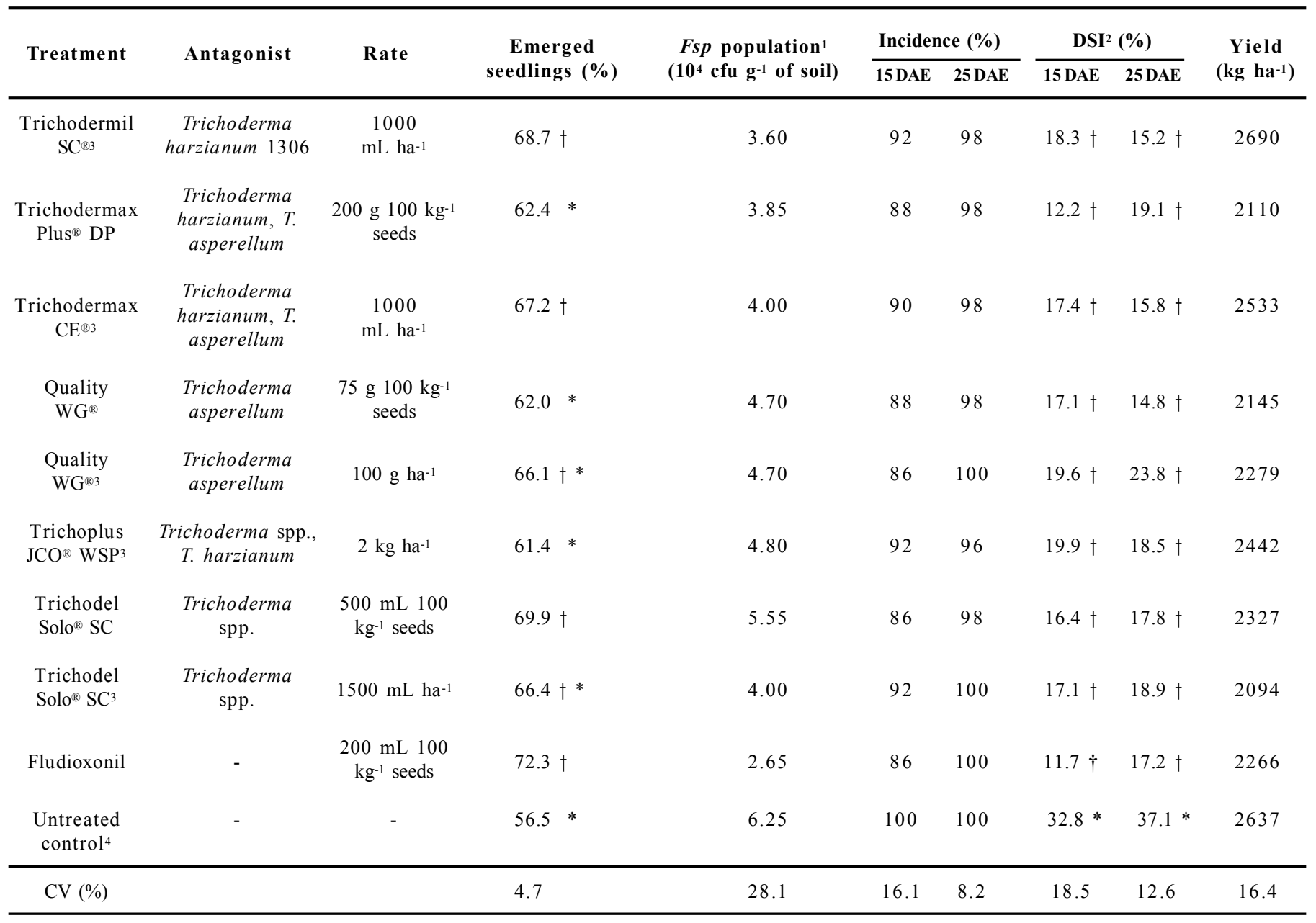

In columns, means followed by $\dagger$ differ significantly from the untreated control and means followed by $*$ differ significantly from fludioxonil, according to Dunnett's test $(P<0.05)$; estimated at 25 days after seedling emergence (DAE); ${ }^{2}$ DSI $(\%)=$ disease severity index; ${ }^{3}$ application in the furrow; ${ }^{4}$ water was applied in the furrow $\left(0.5 \mathrm{~L} \mathrm{~m}^{-1}\right)$. Data of emerged seedlings and cfu of $F s p \mathrm{~g}^{-1}$ of soil were transformed using square root before analysis, but untransformed means are presented. Data of incidence and DSI were transformed using arcsine square root before analysis, but untransformed means are presented.

$\mathrm{CE}^{\circledR}$, both used in the furrow, as well as Trichodel Solo $\mathrm{SC}^{\circledR}$, used for seed treatment, provided emergence which did not differ from that of seeds treated with fludioxonil. The reduction in $F_{s p}$ population density with the application of TCP products and fludioxonil was not significant. Neither Trichoderma products nor fludioxonil significantly affected the incidence of FRR. DSI was $32.8 \%$ at 15 days after emergence (DAE) and $37.1 \%$ at 25 DAE in the untreated control. TCP or fludioxonil reduced DSI to between $11.7 \%$ (fludioxonil used for seed treatment) and $19.9 \%$ (Trichoplus $\mathrm{JCO}^{\circledR}$ WSP used for distribution in the furrow) at $15 \mathrm{DAE}$ and to between 14.8 (Quality $\mathrm{WG}^{\circledR}$ for seed treatment) and $23.8 \%$ (Quality $\mathrm{WG}^{\circledR}$ for distribution in the furrow) at 25 DAE. DSI values obtained with the use of TCP were similar to those obtained with the application of fludioxonil. These data reinforce the use of biocontrol as a highly viable alternative strategy against FRR in common bean. There was no effect of TCP and fludioxonil on bean yield, maybe because plants were not exposed to stressful conditions. Yield reduction in plants infected with $F s p$ may reach $86 \%$ under limiting conditions like soil compaction, excess soil moisture and drought (1). The field results confirmed that the seed treatment was as effective as the distribution of Trichoderma in the furrow for Fsp control. Seed treatment with antagonists could be a feasible strategy to introduce and/or increase the population of these biocontrol agents in areas where soilborne pathogens are already established. The potential of the biological control with isolates of Trichoderma spp. has been reported for F. oxysporum f. sp. phaseoli J. B. Kendr. \& W.C. Snyder in vitro and in greenhouse (5). Applications of T. harzianum Rifai isolate 1306, in Brazilian cerrado fields, have successfully controlled Sclerotinia sclerotiorum (Lib.) de Bary (6) and reduced Fsp population in the soil (7). The present study (Table 1) showed the tendency of TCP and fludioxonil to reduce $F s p$ concentration in the soil $(29.7 \%$ and $57.6 \%$ reduction, respectively, compared to the untreated treatment). Because of this effectiveness against soilborne pathogens, the demand for Trichoderma products has significantly increased in Brazil (3). Trichodermil SC $1306{ }^{\circledR}$ has been recently recorded for application in the furrow to control $F s p$, as well as Rhizoctonia solani J.G. Kühn, in common bean (4). Other TCP available in Brazil require official registration in order to be recommended. No comparative studies involving TCP in common 
bean have been reported for the control of soilborne diseases. Our results showed for the first time in Brazil the effectiveness of TCP in controlling FRR in the field. Regardless the application method, the products were, in general, as effective as the fungicide fludioxonil. This result demonstrates the potential of Trichoderma to be used as a component of integrated disease management programs to control FRR in common bean.

\section{ACKNOWLEDGMENTS}

Research supported by Fapemig and CNPq.

\section{REFERENCES}

1. Abawi, G.S.; Pastor-Corrales, M.A. Root rots of beans in Latin America and Africa: diagnosis, research methodologies, and management strategies. Cali: CIAT, 1990. 114p.

2. Bernardes, T.G.; Silveira, P.M.; Mesquita, M.A.M. Regulardor de crescimento e Trichoderma harzianum aplicados em sementes de feijoeiro cultivado em sucessão a culturas de cobertura. Pesquisa Agropecuária Tropical, Goiânia, v.40, n.4, p.439-446, 2010 .

3. Bettiol, W.; Morandi, M.A.B.; Pinto, Z.V.; Paula Júnior, T.J.; Correa, E.B.; Moura, A.B.; Lucon, C.M.M.; Costa, J.C.; Bezerra, J.L. Bioprotetores comerciais para doenças de plantas. Revisão Anual de Patologia de Plantas, Passo Fundo, v.17, p.27-47, 2009.
4. BRASIL. Ministério da Agricultura, Pecuária e Abastecimento. AGROFIT. Brasília, DF, 2011. Available at: <http:// www.agrofit.agricultura.gov.br/agrofit_cons/ principal_agrofit_cons $>$. Accessed on: 31 Oct. 2011.

5. Carvalho, D.D.C; Mello, S.C.M; Lobo Junior, M.; Silva, M.C. Controle de Fusarium oxysporum f. sp. phaseoli in vitro e em sementes, e promoção do crescimento inicial do feijoeiro comum por Trichoderma harzianum. Tropical Plant Pathology, Brasília, DF, v.36, n.1, p.28-34, 2011.

6. Görgen, C.A.; Silveira Neto, A.N.; Carneiro, L.C.; Ragagnin, V.; Lobo Junior, M. Controle do mofo-branco com palhada e Trichoderma harzianum 1306 em soja. Pesquisa Agropecuária Brasileira, Brasília, DF, v.44, p.1583-1590, 2009.

7. Lobo Junior, M. Controle de podridões radiculares no feijoeiro comum com o fungicida microbiano Trichodermil. In: Cobucci, T.; Wruck, F.J. (Ed.). Resultados obtidos na área pólo de feijão no período de 2002 a 2004. Santo Antônio de Goiás: Embrapa Arroz e Feijão, 2005, p.13-17. (Documentos, 174).

8. Louzada, G.A.S.; Carvalho, D.D.C.; Mello, S.C.M.; Lobo Júnior, M.; Martins, I.; Braúna, L.M. Antagonist potential of Trichoder$m a$ spp. from distinct agricultural ecosystems against Sclerotinia sclerotiorum and Fusarium solani. Biota Neotropica, Campinas, v.9, n.3, p.145-149, 2009.

9. Teixeira, H.; Bettiol, W.; Morandi, M.A.B.; Paula Júnior, T.J.; Pinto, Z.V.; Lehner, M.S.; Freitas, M.M.Q.; Rezende, L.C. Conformidade e qualidade de produtos biológicos para o controle de doenças de plantas. In: Venzon, M.; Paula Júnior, T.J.; Pallini, A. (Ed.). Controle alternativo de pragas e doenças na agricultura orgânica. Viçosa: EPAMIG, UREZM, UFV, 2010. p. 101-115. 